\title{
PERBEDAAN POLA KURVA KEPARAHAN KARIES GIGI SUSU DAN GIGI TETAP SERTA FAKTOR YANG BERPERAN, PADA ANAK DENGAN STATUS GIZI KURANG DAN GIZI BAIK
}

\author{
Poppy Andriany**, Felix A. Joelimar *, Herwati Djoharnas* \\ ** Staf Pengajar Program Studi Kedokteran Gigi Fakultas Kedokteran Unsyiah \\ * Departemen Kedokteran Gigi Komunitas Fakultas Kedokteran Gigi Universitas Indonesia
}

\begin{abstract}
Keywords:
caries, primary dentition, permanent dentition, nutritional status.
\end{abstract}

\begin{abstract}
This study is aimed to describe the pattern of the primary and permanent teeth caries' severity curve within $3-12$ years of age children in a poor and good nutritional status, and to describe the predisposing factors' differences at a certain area in the district of Tangerang which has a high prevalence of poor nutritional status. Method: This study was performed as a cross sectional study. Result: The standardized/ controlled primary dentition caries' scores show that the highest value belongs to the group of 5 years old children with poor nutritional status (10.4), and the caries' scores are higher in the children with poor nutritional status which is one year earlier than the children with good nutritional status whose highest caries score is at 6 years old group (8.00). The highest standardized/ controlled permanent dentition caries' scores in the children with poor nutritional status is at 12 years of age (2.93). Meanwhile, the highest standardized/controlled permanent dentition caries' scores in the children with good nutritional status is at 12 years of age (2.15) as well. It is shown that the caries' scores are higher in the children with poor nutritional status.Conclusions: In this cross sectional study, the result is plotted in curve, shown that in the children with poor nutritional status the curve pattern is higher than the children with good nutritional status at the same age (3-12 years of age). It is also shown the same phenomenon at both groups of 6-12 of age, which means that there is a positive correlation between primary dentition caries and permanent dentition caries. The most obvious predisposing factors in the caries severity is the salivary $\mathrm{pH}$.
\end{abstract}




\section{Pendahuluan}

Gizi merupakan kebutuhan utama dalam setiap proses kehidupan manusia agar dapat tumbuh dan kembang sesuai potensinya secara optimal. Pembentukan struktur gigi yang sehat dan sempurna didukung oleh gizi yang cukup. Berbagai zat gizi penting dalam proses pembentukan dan perkembangan gigi baik gigi susu maupun gigi tetap. Kekurangan satu atau lebih zat gizi dapat berakibat tidak sempurnanya pembentukan dan perkembangan gigi. ${ }^{1}$ Defisiensi moderat protein selama masa pertumbuhan akan memperlambat erupsi gigi insisif dan molar susu. ${ }^{2}$

Ramy R dkk (1986) melaporkan bahwa gizi mempengaruhi waktu erupsi gigi susu. Beberapa penelitian pada anak-anak yang mengalami gizi kurang melaporkan karies gigi pada anak gizi kurang lebih tinggi daripada anak yang normal.,4,5 Alvarez (1989) melakukan penelitian secara cross sectional pada anak dengan status gizi kurang dan status gizi baik. Berdasarkan penelitian di atas maka Alvarez membuat hipotesa bahwa apabila dilakukan penelitian karies gigi secara cross sectional pada anak-anak umur 6-15 tahun, maka pada populasi ini akan di amati korelasi negatif antara karies gigi susu dan gigi tetap. Anak-anak dengan keadaan gizi baik akan memperlihatkan nilai karies pada gigi susu yang lebih sedikit dan nilai karies yang lebih tinggi pada gigi tetap. Sebaliknya dengan anak dengan gizi kurang, akan memperlihatkan prevalensi karies yang lebih tinggi pada gigi susu tetapi akan mempunyai karies yang lebih rendah pada gigi tetap. Pola perkembangan karies terhadap umur secara cross sectional tidak saja memperlihatkan hubungan negatif antara karies gigi susu dan gigi tetap tetapi juga memperlihatkan pergeseran kurva karies gigi susu ke kanan pada anak-anak malnutrisi, karena terlambatnya erupsi dan eksfoliasi gigi susu. $^{6,7}$

Penelitian Alvarez (1989) ini bertentangan dengan penelitian yang dilakukan Hill dkk (1967) secara longitudinal, bahwa anak yang prevalensi karies rendah pada gigi susu juga menunjukkan karies yang rendah pada gigi tetap. Pada anak-anak Hungaria, Scott, dan Swedia ada hubungan yang positif antara karies gigi susu dan gigi tetap, sehingga ada pertentangan pola karies gigi susu dan gigi tetap pada anak gizi kurang dan gizi baik yang diperoleh secara cross sectional dan longitudinal. ${ }^{8,9}$

Kelemahan dari penelitian Alvarez karena hanya melihat prevalensi karies berdasarkan umur, tidak dilihat dari jumlah gigi yang masih ada terutama pada anak gizi kurang erupsi gigi tetapnya lambat karena eksfoliasi gigi susunya juga lambat sehingga karies gigi susunya tercatat lebih banyak dan karies gigi tetapnya tercatat lebih sedikit, yang juga mempengaruhi prevalensi karies, sehingga dianggap perlu untuk melakukan penelitian lanjut dengan melihat karies dari jumlah gigi yang ada dan bagaimana gambaran kurva deft dan DMFT dari jumlah gigi susu dan gigi tetap.

\section{Bahan dan Metoda}

Bahan yang di gunakan untuk pemeriksaan gigi adalah kaca mulut, sonde, lampu halogen, mikrotoa dengan ketelitian 0,1 cm, timbangan berat badan. Cara kerja : Pengisian form identifikasi (no responden, tanggal pemeriksaan, kelurahan, SD, posyandu nama, jenis kelamin, tanggal lahir), Pengukuran tinggi badan dan berat badan, pemeriksaan karies dan jumlah gigi.

Penelitian dilakukan dengan potong lintang (cross sectional), yang pengukuran variabel-variabelnya di lakukan hanya satu kali.

\section{Tempat penelitian}

Lokasi yang dipilih dalam penelitian ini adalah kecamatan Neglasari kota Tangerang, yang ditentukan berdasarkan data status gizi anak balita dimana kecamatan Neglasari kota Tangerang yang memiliki angka status gizi 
buruk balita yang paling tinggi di kota Tangerang

Populasi yang diambil dalam penelitian ini dilakukan pada anak balita yang berada di posyandu kecamatan Neglasari dan muridmurid Sekolah Dasar yang berada di kecamatan Neglasari kota Tangerang.

Prosedur pengambilan subyek penelitian dengan cara purposive sampling, yang ditentukan berdasarkan data status gizi anak balita yang memiliki status gizi kurang yang tinggi. Subyek pada penelitian ini adalah anak balita usia 3-5 tahun yang berkunjung di posyandu. dan murid-murid sekolah dasar kelas I - VI yang berusia 6-12 kecamatan Negalasari kota tangerang.

\section{Hasil}

\section{Pola Kurva}

\section{Kurva 1.}

Rata-rata karies gigi susu kelompok umur 3-12 tahun dengan status gizi baik dan gizi kurang

( Standardisasi )

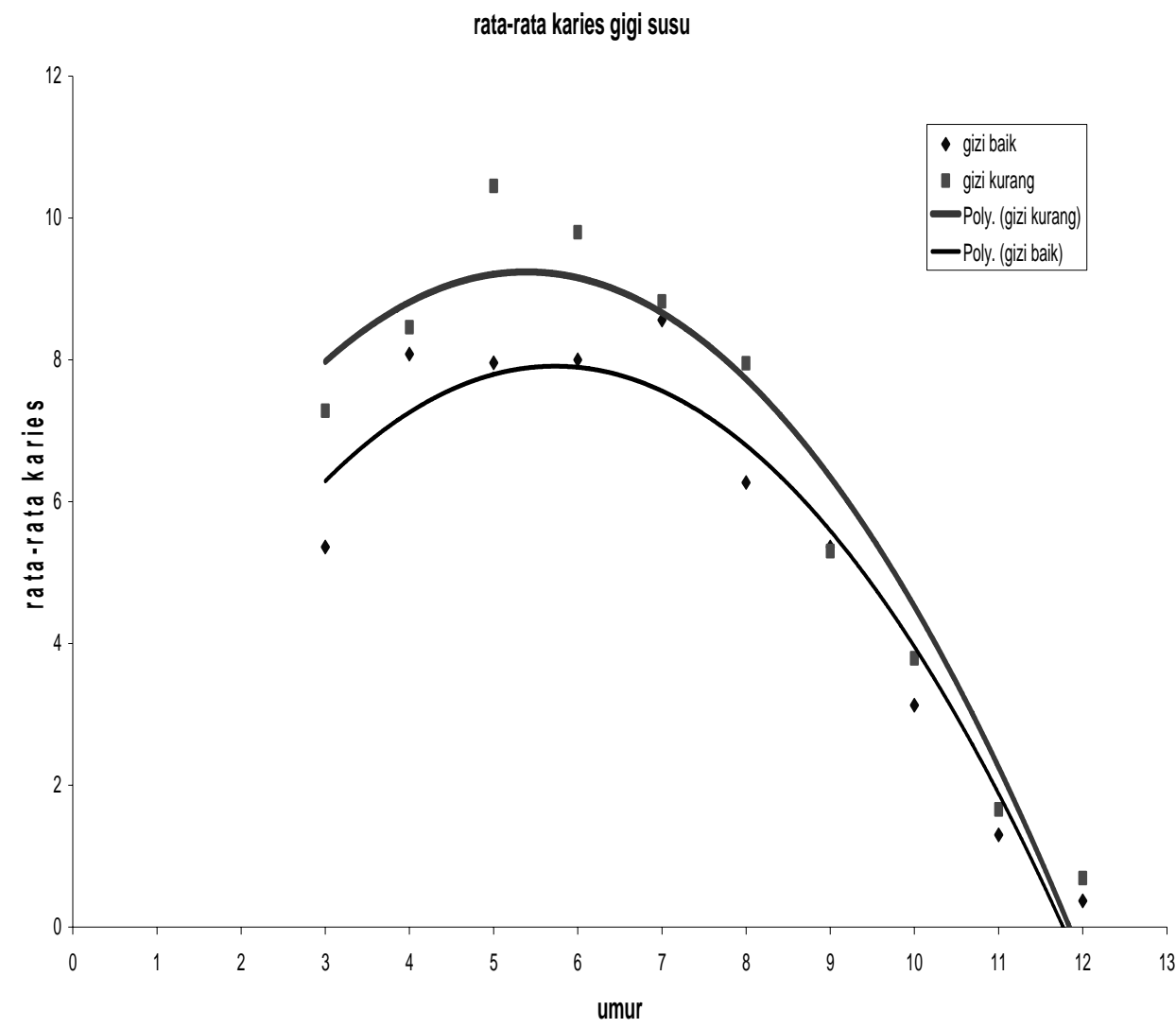

Kurva 1. memperlihatkan skor karies gigi susu kelompok umur 3-12 tahun yang telah distandarisasi/dikontrol dengan jumlah gigi dan di plotkan dalam bentuk kurva dimana kurva status gizi baik lebih rendah daripada gizi kurang. Puncak tertinggi pada anak gizi kurang yaitu pada kelompok umur 5 tahun, lebih awal 1 tahun dari pada anak gizi baik. 


\section{Kurva 2.}

Rata-rata karies gigi tetap kelompok umur 6-12 tahun dengan status gizi baik dan gizi kurang

( Standardisasi )

rata-rata karies gigi permanen

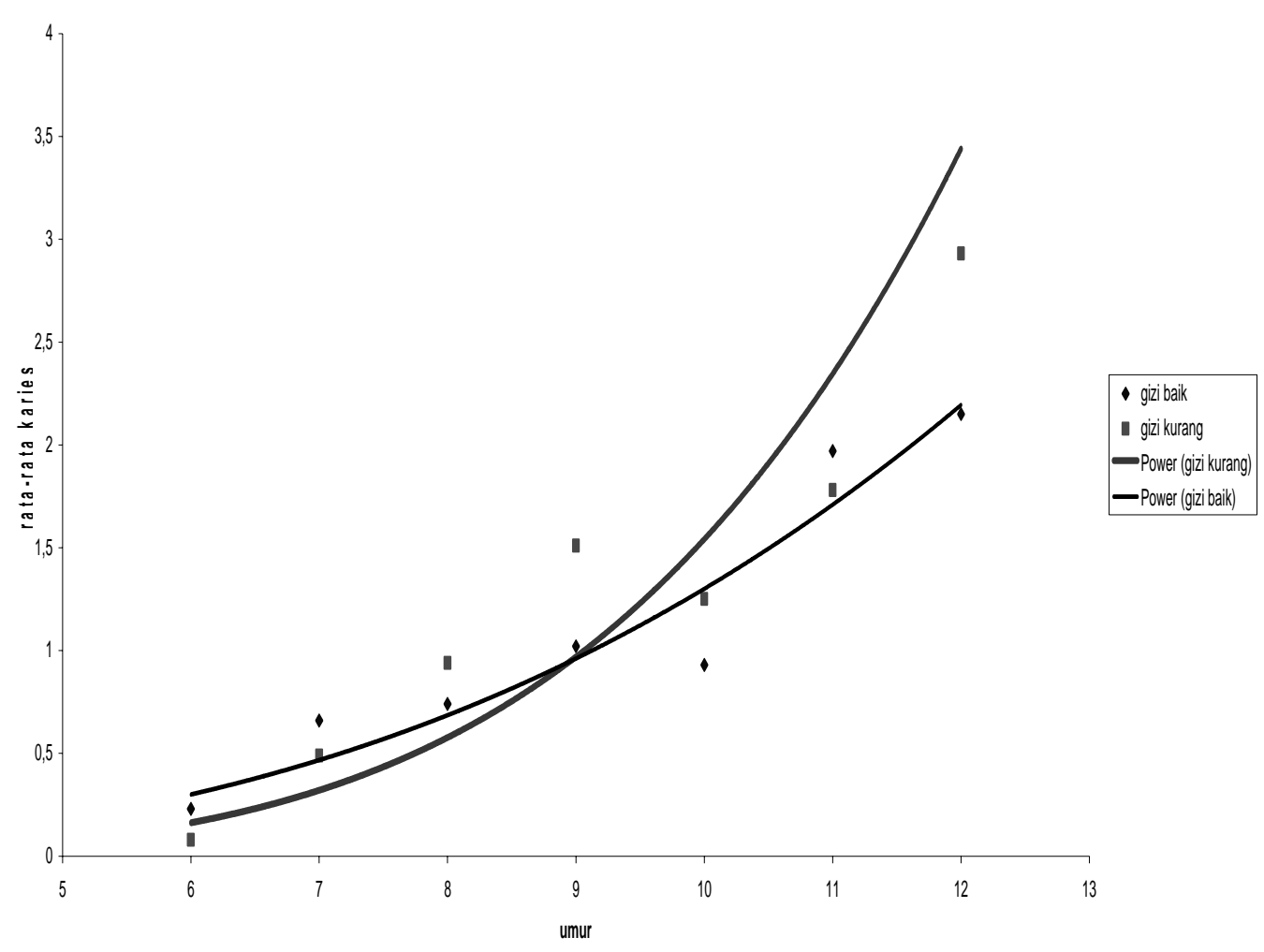

Kurva 2. memperlihatkan skor karies gigi tetap kelompok umur 6-12 tahun yang telah distandarisasi/dikontrol dengan jumlah gigi dan diplotkan dalam bentuk kurva dimana kurva status gizi baik lebih rendah daripada gizi kurang pada anak $>9$ tahun. Puncak tertinggi yaitu pada kelompok umur 12 tahun pada anak gizi baik maupun anak gizi kurang.

\section{Pembahasan}

1. Aspek metoda cross sectional tanpa kontrol variabel jumlah gigi dan metoda cross sectional dengan kontrol variabel jumlah gigi

Pada penelitian Alvarez menggunakan metoda penelitian cross sectional tanpa dikontrol variabel jumlah gigi diperoleh hasil yang bertentangan dengan penelitian menggunakan metoda longitudinal. Pada penelitian Alvarez ini anak gizi kurang karies gigi susunya lebih tinggi daripada karies gigi tetap dan anak gizi baik karies gigi susu nya lebih rendah daripada gigi tetap. Pada penelitian metoda longitudinal (Hill dkk) diperoleh karies gigi susu dan tetap anak gizi kurang lebih tinggi daripada anak gizi baik. ${ }^{35}$ Penelitian di kecamatan Neglasari dengan menggunakan metoda yang sama dengan Alvarez yaitu metoda cross sectional dengan kontrol variabel jumlah gigi diperoleh hasil yang sama dengan longitudinal. ${ }^{6,7}$

2. Standarisasi jumlah gigi untuk memperoleh dampak murni (net effect) 
variabel umur terhadap karies pada kelompok gizi kurang dan gizi baik

Pada penelitian cross sectional yang terdahulu (Alvarez), terlihat kontradiktif dengan penelitian longitudinal pada anak-anak Hungaria, Scott dan Swedia. Hal ini diduga disebabkan perbedaan jumlah gigi susu maupun gigi tetap diantara kedua kelompok anak. Anak yang gizi buruk erupsi gigi tetapnya lambat karena eksfoliasi gigi susunya juga lambat, sehingga karies gigi susunya tercatat lebih banyak dan karies gigi tetapnya tercatat lebih sedikit, semata-mata karena jumlah gigi susunya lebih banyak daripada normal dan jumlah gigi tetapnya lebih sedikit daripada normal.

Oleh karena adanya perbedaan jumlah gigi yang berpengaruh terhadap tinggi rendahnya risiko karies serta berpengaruh pula terhadap pencatatan skor karies, maka perlu dilakukan standarisasi jumlah gigi di antara kedua kelompok anak ini.

Standardisasi dapat digunakan dalam analitik pada survey crossecsional. Standardisasi dianggap sebagai alat tambahan untuk mengklarifikasi analisis crosstabulation.

Dengan menggunakan standardisasi kita dapat menghitung rata-rata karies gigi susu dan gigi tetap anak dengan status gizi kurang dan gizi baik yang dikontrol dengan jumlah gigi susu dan jumlah gigi tetap menurut umur. Secara keseluruhan rata-rata karies berubah, walaupun sangat sedikit tetapi mengikuti standardisasi. ${ }^{10}$

3. Karies gigi susu dan gigi tetap berdasarkan status gizi pada kelompok umur 3-12 tahun

Skor rata-rata karies gigi dari sekelompok anak yang umurnya berbeda tidak bisa kita jadikan patokan sebagai skor rata-rata karies, melainkan kita ambil dari umur tertentu sebagai representasi skor karies karena skor karies tergantung umur dan jumlah gigi. Makin bertambah umur makin banyak karies. Setelah umur 7 tahun mulai ada gigi yang tanggal, jadi dengan demikian skor karies gigi susu juga menurun. Skor karies gigi susu yang kita ambil untuk representasi adalah umur 6 tahun manakala gigi susu masih lengkap.
Pada penelitian ini skor karies gigi susu yang telah distandarisasi/dikontrol dengan jumlah gigi skor tertinggi pada anak gizi kurang yaitu umur 5 tahun (10.4) dimana 1 tahun lebih awal daripada anak gizi baik yaitu 6 tahun (8.00) dan terlihat bahwa skor karies anak gizi kurang lebih tinggi daripada anak gizi baik.

Skor karies gigi tetap yang kita ambil untuk representasi adalah umur 12 tahun (WHO), manakala gigi tetap telah lengkap. Pada penelitian ini skor karies gigi tetap yang telah distandarisasi/dikontrol jumlah gigi pada anak gizi kurang skor tertinggi yaitu umur 12 tahun (2.93) dan pada anak gizi baik (2.15) dan dan terlihat bahwa skor karies anak gizi kurang lebih tinggi daripada anak gizi baik.

Hasil penelitian menunjukkan adanya korelasi positif antara karies gigi susu dan karies gigi tetap artinya anak dengan gizi baik memperlihatkan karies gigi susu dan gigi tetap yang rendah sedangkan pada anak dengan gizi kurang memperlihatkan karies gigi susu dan gigi tetap yang tinggi.

Menurut Hill dkk, penelitian yang dilakukan secara longitudinal ada hubungan yang positif antara karies gigi susu dan karies gigi tetap. Artinya anak yang rata-rata karies rendah pada gigi susu juga menunjukkan karies yang rendah pada gigi tetap. ${ }^{9}$

Penelitian di Kecamatan Neglasari ini dilakukan pada anak umur 3-12 tahun yang diperiksa skor karies gigi susu dan karies gigi tetapnya. Jadi pemeriksaan karies gigi susu maupun karies gigi tetap dilakukan dalam mulut yang sama, kecuali pada anak umur 3-5 tahun yang hanya memiliki gigi susu. Sehingga boleh dikatakan penelitian ini "Quasi Longitudinal”.

\section{Kajian Kurva karies gigi susu dan gigi tetap berdasarkan status gizi anak pada kelompok umur 3-12 tahun.}

Dari data skor karies gigi susu yang telah distandarisasi/dikontrol dengan jumlah gigi yang kemudian diplotkan dalam bentuk kurva (kurva 1), terlihat bahwa kurva karies gigi susu anak gizi kurang pada kelompok umur 3-12 tahun lebih tinggi daripada kurva karies anak dengan gizi baik pada kelompok umur yang sama. Pola kurva yang dihasilkan berbentuk bell 
shaped artinya makin bertambah umur makin banyak karies, namun kemudian mulai ada gigi susu yang tanggal dengan demikian skor karies juga menurun sehingga kurva yang dihasilkan berbentuk bell shaped. Puncak dari kurva ini yaitu pada umur 6 tahun pada anak gizi baik dan 5 tahun pada gizi kurang.

Kurva 2 menunjukkan skor karies gigi tetap yang telah di standarisasi/dikontrol dengan jumlah gigi, terlihat bahwa pada kelompok umur 6-12 tahun kurva karies anak gizi kurang lebih tinggi daripada anak gizi baik. Pola kurva yang dihasilkan hampir berbentuk garis diagonal, artinya skor karies bertambah dengan sejalannya umur dan skor karies tertinggi yaitu pada umur 12 tahun dimana gigi tetap telah lengkap.

Kurva 1 dan 2 tidak menunjukkan shift to the right, sedangkan kurva pada penelitian Alvarez menunjukkan shift to the right antara anak gizi baik dan gizi buruk (stunting).

\section{Aspek faktor predisposisi pH saliva, makanan kariogenik dan kebersihan mulut berdasarkan status gizi.}

Pada penelitian ini faktor yang paling berperan pada perbedaan keparahan karies adalah $\mathrm{pH}$ saliva. Makanan kariogenik dan kebersihan mulut tidak berbeda bermakna, hal ini disebabkan karena pola jajan anak yang sama, yaitu pada umumnya makan makanan yang berisiko terjadinya karies (skor buruk) dan kebersihan mulut anak gizi baik dan gizi kurang juga sama (skor sedang).

Skor karies anak malnutrisi tinggi karena pada anak malnutrisi perkembangan kelenjar saliva mengalami atropi sehingga menyebabkan aliran saliva menurun dan mengurangi buffer saliva yang akhirnya dapat meningkatnya terjadi karies. $^{11}$

Johansson dkk (1992) mengatakan ada hubungan antara kronik malnutrisi dan sekresi saliva yang dirangsang. Laju aliran saliva dan buffer saliva berbanding terbalik dengan malnutrisi dan karies gigi. ${ }^{12}$

Banyak faktor yang menyebabkan meningkatnya karies gigi (percobaan pada tikus) yang malnurisi protein dan energi ; menyebabkan berkurangnya aliran saliva, mempengaruhi komposisi saliva, merubah sistem imun dan meningkatnya daya larut email dalam asam. ${ }^{12,13}$

\section{Daftar Acuan}

1. Sri S. Nasar. Aspek Nutrisi Pada Kesehatan Gigi Anak. Jurnal Kedokteran Gigi Universitas Indonesia Vol 4 Edisi Khusus KPPIKG XI .1997 ; 388-392.

2. P Cleaton-Jones, Ruth Sinwell, Mirriam Mogotsi, Barbara. Nutritional Status and Dental Caries in a Large sample of 4- and 5 year old South African Children . S A J Clin. 2000 : Vol 13 : No 3

3. Rami Reddy V, Vijayalakshmi PB, Chandrasekhar RB. Deciduous tooth emergence and physique of Velema children of Southeastern Andhra Pradesh, India. Acta Odontol Pediatr. 1986;7:1-5. [PubMed] dalam ; Poster W.J, Reid, Katz; Malnutrition and dental caries : A Review of the literature . Caries Res. 2005; 39 (6); 441-447

4. Cleaton-Jones P, Richardson BD, Granath L, Fatti LP, Sinwell R, Walker AR, Mogotsi M. Nutritional status and dental caries in a large sample of 4- and 5-year-old South African children. S Afr Med J. 2000;90:631-635. [PubMed]

5. Li Y, Navia JM, Bian JY. Caries experience in deciduous dentition of rural Chinese children 35 years old in relation to the presence or absence of enamel hypoplasia. Caries Res. 1996;30:815. [PubMed]

6. Alvarez JO, Eguren JC, Caceda J, Navia JM. The effect of nutritional status on the age distribution of dental caries in the primary teeth. J Dent Res. 1990;69:1564-1566. [PubMed]

7. Alvarez JO, Navia JM. Nutritional Status, Tooth Eruption, and Dental Caries: a review . Am J Clin Nutr 1989; Vol 49 : 417-426.

8. Alvarez JO, Navia JM. Nutritional Status, Tooth Eruption, and Dental Caries: a review . Am J Clin Nutr 1989; Vol 49 : 417-426. Y.Li dan W. Wang. Predicting Caries in Permanen Teeth From Caries in Primary Teeth : An Eight-year Cohort Study. J. Dent Res 81 (8): 561-566, 2002.

9. Hill et al. Deciduos teeth and future caries experience. J Am Dent Assoc 1967 ; 74 : 430-8 in: Alvarez JO, Navia JM. Nutritional Status, 
Poppy Andriany, Felix A. Joelimar, Herwati Djoharnas

Tooth Eruption, and Dental Caries: a review . Am J Clin Nutr 1989; Vol 49 : 417-426.

10. T.W. Pullum. Standardization (World Fertility Survey). Director. Center for Studies in Demography and Ecology, DK-40 University of Washington. Agustus. 1978.

11. Johansson I. et al. Saliva Composition in Indian Children with Chronic Protein-Energy Malnutrition. J Dent Res. 73 (1) : 11-19 january 1994.
12. Johansson I, Saellstrom, Rajan B.P, Parameswaran A. Salivary Flow and Dental Caries in Indian Children Suffering from Chronic Malnutrition. Caries Res ;1992 : Vol 26: 38-43.

13. Alvarez J.O. Nutrition, Tooth Development And Dental Caries. Am.J Clin Nutr 1995 ; 61 :410416 